\title{
The Impact of Macroeconomic and Banking Factors on Credit Growth in the Albanian Banking System
}

\author{
Dr. Ali Shingjergji \\ Msc. Marsida Hyseni \\ Lecturers in Portfolio Management and Investment Management \\ Finance and Accounting Department, Faculty of Economy \\ University of Elbasan "Aleksandër Xhuvani" Rruga "Kozma Naska" 3001, Elbasan, Albania \\ ali.shingjergii@gmail.com \\ marsi-hyseni@hotmail.com
}

\begin{abstract}
The aim of this paper is to analyze the influence of some macroeconomic and banking factors on credit growth in the Albanian banking system. From the literature review is noticed that the credit growth in the banking system is influenced by both macroeconomic and banking factors. We use credit growth as a dependent variable while as independent variables we use: GDP growth, inflation rate, unemployment rate, loan interest rate, capital adequacy ratio, bank size and NPL ratio. The relationship between credit growth and macroeconomic and banking factors was tested by using a regression model like the ordinary least squares (OLS). We take into consideration a period from 2002 - 2013 using quarterly panel data for the whole Albanian banking system with a total of 48 observations per each variable. The regression results find out that the credit growth in the Albanian banking system is positively related to GDP growth, inflation rate and capital adequacy ratio while is negatively related to unemployment rate, interest rate, non performing loans and bank size.
\end{abstract}

Keywords: banking system, credit growth, macroeconomic factors, banking factors

JEL classification: G2, G21

\section{Introduction}

The Albanian banking system is the most important sector of the financial system in Albania. It occupies $85 \%$ of the financial system and in the same time demonstrating the weak role of the capital markets in our country. As a result the analysis of the banking system and the credit sector takes a crucial role for the whole financial system in Albania. In fact we have to notice that from $2002-2008$ the quarterly credit growth of the Albanian banking system was approximately $10.07 \%$. We have to emphasize that as a result of the global financial crises even the Albanian banking system was affected. The negative results of the global financial crises were reflected in two main directions: the first is the reduction of the credit growth from 2009 - 2013 which is almost one third (3\%) if compared to the previous period, and secondly is related to the progressive growth of the non performing loans that goes from $3 \%$ in the first trimester of 2008 to $25 \%$ in the fourth trimester of 2014. In these conditions the Albanian banking system is suffering from a credit crunch because from the first trimester of 2013 until now we have a reduction of the credit growth. According to the Bank of Albania the low demand of economic agents and the conservative attitude of the banks are the main reasons that have led to the credit slowdown the last 5 years. In the context of overall macroeconomic developments, where the performance of economic activity remains sluggish, the demand for money from economic agents is estimated to be low. On the other side (supply) the banks despite being well capitalized and liquid keep still tightened the credit conditions and are very selective towards different projects that need to be financed. The weak performance of credit in foreign currency has reflected the customer preferences shift from foreign currency to local currency especially in mortgage loans to individuals and loans for liquidity purposes of business. In this context is to notice that the developments of credit performance have reflected on the other macroeconomic developments in our country and the slowdown of aggregate demand was followed by reduction of credit demand both from businesses and individuals. 


\section{Literature review}

A lot of academic research is done in order to investigate the relationship between loans level and the macroeconomic and banking factors. Below we a give a short literature review of the main authors that have tried to determine the main factors that influence the loans level in the different banking systems.

Constant, Fouopi Djiogap and Augustin Ngomsi (2012) analyze the determinants bank long-term lending behavior in the central African economic and monetary community using data from 35 commercial banks of six African countries of the CEMAC over the period 2001-2010 using a regression analysis. They use two dependant variables: first is the ratio of bank long-term business loans to total assets and second is the ratio of bank business loans to total assets. As independent variables the authors use: bank size, capital to asset ratio, long term liabilities, NPL, ownership type, inflation and GDP growth. According to the regression results is to emphasize that bank size, GDP growth and capital-to assets ratio are positive and statistically significant in both analysis. This means that larger and well capitalized banks are more willing to grant business loans. The relationship between NPL and the long-term loans to assets ratio is positive while there is no relationship between inflation rate and long-term loans ratio.

Francisco Rodriguez and Santiago Carbo- using longitudinal data analysis find out that some factors such as bank size, relationship lending, the weight of mutual funds, different measures of bank concentration and efficiency have been specially significant for both bank specialization in lending activities and the loan to deposit rate spread. On the other hand according to Serpil Tomak (Vocational School of Social Sciences, Mersin University Turkey) he suggests that private banks loans performance is better than state-owned commercial bank, even though this study shows that the business loans depends on its size, liabilities, non performing loans to total loans (NPL) and inflation rate. They study the bank-level (size and access to funds) and market-based (interest, rate, inflation rate, GDP) variables that impact on leading banks in Turkey. If Serpil Tomak comes in a conclusion that the private banks loans performance is better than state-owned commercial bank, the study of Lucky Chernukh and Alexandra K. Theodossiou (2011) highlight the importance of bank-level constraints in extending vital long-term credit to firms. They use a large sample of Russian banks, and find out that the median bank allocates only $0,5 \%$ of its assets in long-term business loans and that there is wide cross-sectional variation on this ratio among banks. The Department of Banking and Finance in Ghana (2013) study the behavior of bank lending; using the GMM-system estimator developed by Arellano and Bover (1995) also Blundell and Bond (1998). They find that the bank size and capital structure have a statistical significant and positive relationship with bank lending behavior. In this study they also find negative evidence and significant impact of some macroeconomic indicators (central bank lending rate and exchange rate) on bank lending behavior. The relationship of the bank although the negative evidences come out in a conclusion that this, policies aimed at maintaining stable macroeconomic fundamentals would greatly accelerate bank lending decision. On another side we have evidences how bank characteristics and the institutional environment influence the composition of banks' loan portfolio. Ralph De Haas, Daniel Ferreira, Anita Taci (2010) have used a new and unique data set based on the ERBD Banking Environment and Performance Survey (BEPS), which was conducted for 220 banks in 20 transition countries. They show that all this criteria like bank ownership, bank size and legal creditor protection are important determinants of the composition of banks' loan portfolios. We have even an examination of the changes in bank credit across a wide range of emerging market economies during the last decade which was made by Kai Guo and Vahram Stepanyan (2011). The results show that domestic and foreign funding tend to contribute positively and symmetrically to credit growth, and high inflation, while increasing nominal credit, is detrimental to real credit growth. They also find that loose monetary conditions, either domestic or global, result in more credit, and that the health of the banking sector also matters. The bank officer of (BSP) Ms. Tan (2012) explains that despite robust growth, credit growth has been sluggish in the Philippines. At these banks analysis suggests that interests margins in the Philippines rise with bank size, bank capitalization, foreign ownership, overhead costs and tax rates.

Using bank-level data for a number of Asian economies, they find that if the economy increases, we have lower inflation, higher reserve requirements, greater banking sector development, smaller stock market development and lower government deficits reduce net interest margins, informing the policy debate on strengthening financial intermediation in the Philippines. Gerti Shijaku \& Irini Kalluci from the Albanian Bank are focused on identifying and evaluating the long run determinants of bank credit to the private sector by employing a Vector Error Correction Mechanism (VECM) approach based on demand and supply indicators. The results imply that lending is positively linked to economic growth. Further, banking and financial intermediation, as well as financial liberalization would stimulate higher lending demand. In addition, lower cost of lending, diminishing government domestic borrowing and a more qualitative bank credit would 
create further lending incentives. At the same time, the exchange rate is found to pick up some demand valuation and consumption smoothing effects.

\section{Data, methodology and hypothesis}

In this paper we use two main data sources: the national institute of statistics (INSTAT) for the macroeconomic data and the Albanian association of banks (AAB) for the banking data. We take into consideration the period from $2002-2013$ using quarterly data for the whole banking system with 48 observations for each variable. To test the relationship between the dependant variable (credit growth) and the independent variables (macroeconomic and banking) we use a regression analysis like the ordinary least squares. The macroeconomic variables used in this study are as follows:

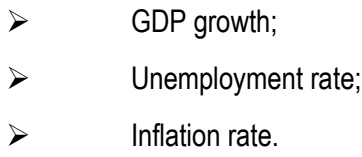

While as bank variables we comprise:

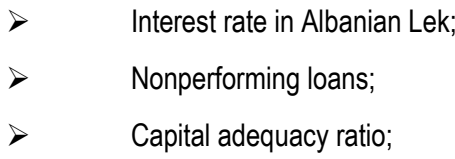

$>\quad$ Bank size measured by total assets.

From literature review is noticed that credit growth is influenced by both macroeconomic and banking variables.

In fact if we want to analyze the relationship between GDP growth and credit growth is to emphasize that we expect a positive relationship between these two variables. A GDP growth usually is followed by good macroeconomic conditions and usually is noticed an expansion of credit growth. From here we can derive the fist hypothesis as follows:

\section{Hypothesis \#1. There is a positive relationship between GDP growth and credit growth.}

The second macroeconomic variable used in this paper is the unemployment rate. From previous researches is noticed $\mathrm{e}$ negative relationship between unemployment rate and credit growth. In fact an increase of unemployment rate will determine a reduction of credit growth because individuals have lower incomes and tend to lower the demand for credit. From here we can derive the second hypothesis:

\section{Hypothesis \#2. There is a negative relationship between the unemployment rate and credit growth.}

The third macroeconomic variable is the inflation rate. We expect a positive relationship between inflation rate and credit growth because a rise in inflation rate will result to higher demand for nominal credit. From here we derive the third hypothesis as follows:

\section{Hypothesis \#3. There is a positive relationship between inflation rate and credit growth.}

Regarding the relationship between the banking variables and credit growth we take into consideration several variables. The first one is related to the relationship between the credit interest rate in Albanian Lek and credit growth. In fact we expect a negative relationship between interest rate and credit growth because an increase of interest rates determines a reduction of credit growth. This result derives from the fact that when banks increase credit interest rates the individuals or businesses tend to lower their demand for credit. From here we can derive the fourth hypothesis: 


\section{Hypothesis \#4. There is a negative relationship between credit interest rates and credit growth.}

We expect a negative relationship between the nonperforming loans and credit growth. In fact if banks have high nonperforming loans ratios they tend to lower their credit supply in order to be more cautious. From here we can derive the fifth hypothesis as follows:

\section{Hypothesis \#5. There is a negative relationship between the nonperforming loans and credit growth.}

We expect a positive relationship between the capital adequacy ratio (CAR) and the credit growth. In fact banks with higher levels of loans are required to have higher level of capital adequacy ratio. From here we can derive the sixth hypothesis as follows:

\section{Hypothesis \#6. There is a positive relationship between capital adequacy ratio and the credit growth.}

We expect a positive relationship between bank size and credit growth. In fact if banks expand their assets usually they tend to increase the level of credit. From here we can derive the seventh hypothesis as follows:

Hypothesis \#7. There is a positive relationship between bank size and credit growth.

\section{Descriptive statistics and regression results}

In table 1 we see the descriptive statistic of all the variables taken into consideration during the period of the study from 2002 - 2013. The dependant variable (credit growth) has an average of $6.35 \%$ with a standard deviation of $5.57 \%$. We have to emphasize that especially after global financial crises the credit growth was increasing lower and actually is almost stable.

The unemployment rate has an average of $14.14 \%$ during the period of study with a very low standard deviation of only $1.19 \%$ showing an almost constant trend. In fact is thought that the real unemployment rate in Albania is very far from the official data because a lot of unemployed people do not want to register on employment offices.

Regarding the GDP growth we have to notice that is has an average of $2.8 \%$ and a standard deviation of $10.7 \%$. In the case of Albania the GDP growth has suffered from the global financial crises and actually is in very low levels compared to the previsions.

The average inflation rate during the study period was $2.9 \%$ with a standard deviation of $1.13 \%$. From here we can say that price stability in the Albanian Financial System has been very stable and within the objectives of the Bank of Albania which have set an inflation target of $3 \% \pm 1 \%$.

Table 1. Descriptive Statistic

\begin{tabular}{|lllll|}
\hline Variable & Mean & Std. Deviation & Min & Max \\
\hline Cr_Gr & 0.0635 & 0.0557 & -0.0520 & 0.2347 \\
\hline UNP & 0.1414 & 0.0119 & 0.1110 & 0.1700 \\
\hline GDP_Gr & 0.0280 & 0.1070 & -0.1309 & 0.2830 \\
\hline INF & 0.0290 & 0.0113 & 0.0080 & 0.0720 \\
\hline
\end{tabular}




\begin{tabular}{|lllll|}
\hline INT_ALL & 0.1374 & 0.0171 & 0.0967 & 0.1775 \\
\hline NPL & 0.0969 & 0.0748 & 0.0233 & 0.2422 \\
\hline CAR & 0.1784 & 0.0288 & 0.1000 & 0.2451 \\
\hline Ln_TA & 12.3732 & 0.9261 & 10.7986 & 13.3823 \\
\hline
\end{tabular}

Regarding the loans interest rates in the Albanian banking system we have an average of $13.74 \%$ with a standard deviation of $1.71 \%$, showing an almost constant trend during $2002-2013$. We also have to notice that loan interest rates in Albania are between the highest in the region of Balkans.

The non performing loans ratio has an average of $9.69 \%$ of the total loans with a standard deviation of $7.48 \%$. It is to emphasize that actually the Albanian banking system is suffering from a high level of NPL ratio like $23.50 \%$ in the end of 2013. This high NPL ratio is very concerning for the whole banking system and an immediate solution must be founded in order to save the whole financial system from a collapse.

Table 2. Correlation Matrix

\begin{tabular}{|lllllllll|}
\hline Variables & Cr_Gr & UNP & GDP_Gr & INF & INT_ALL & NPL & CAR & Ln_TA \\
\hline Cr_Gr & 1.00 & -0.05 & 0.39 & 0.12 & 0.39 & -0.77 & 0.60 & -0.52 \\
\hline UNP & -0.05 & 1.00 & -0.01 & 0.17 & 0.27 & -0.04 & 0.14 & -0.51 \\
\hline GDP_Gr & 0.39 & -0.01 & 1.00 & 0.12 & -0.01 & -0.15 & 0.27 & -0.12 \\
\hline INF & 0.12 & 0.17 & 0.12 & 1.00 & 0.44 & -0.21 & -0.20 & -0.27 \\
\hline INT_ALL & 0.39 & 0.27 & -0.01 & 0.44 & 1.00 & -0.71 & 0.23 & -0.80 \\
\hline NPL & -0.77 & -0.04 & -0.15 & -0.21 & -0.71 & 1.00 & -0.47 & 0.70 \\
\hline CAR & 0.60 & 0.14 & 0.27 & -0.20 & 0.23 & -0.47 & 1.00 & -0.46 \\
\hline Ln_TA & -0.52 & -0.51 & -0.12 & -0.27 & -0.80 & 0.70 & -0.46 & 1.00 \\
\hline
\end{tabular}

The capital adequacy ratio (CAR) has an average of $17.84 \%$ with a standard deviation of only $2.88 \%$. In fact is to notice that the average CAR of $17.84 \%$ is quite higher than the regulatory level of $12 \%$ imposed by the supervising authorities. From here we can say that the Albanian banking system is well capitalized despite the big problems is recently facing.

The total assets of the Albanian banking system have seen a progressive growth especially until 2009. After the global financial crises the banks were more prudent to grant new loans and this had a negative impact in the economy of Albania and the reduction of the liquidity in the business sector.

After analyzing the data with Microfit 5.0 software we have the regression results as follows (table 3):

* The regression analysis confirms that the coefficient of determination, R-Squared, is equal to $87.30 \%$ and shows that the independent variables explain $87.30 \%$ of the variation of the credit growth in the Albanian banking system, while the remaining part $(12.70 \%)$ is explained by other factors that are not included in this study. 
Table 3. Regression Results*

\begin{tabular}{|lllll|}
\hline Variables & Beta & Std. Error & T-value & Sig \\
\hline Constant & 0.441 & 0.242 & 1.825 & 0.076 \\
\hline UNP & -0.661 & 0.499 & -1.324 & 0.193 \\
\hline GDP_Gr & 0.091 & 0.044 & 2.056 & 0.046 \\
\hline INF & 0.592 & 0.473 & 1.251 & 0.218 \\
\hline INT_ALL & -1.197 & 0.530 & -2.260 & 0.029 \\
\hline NPL & -0.533 & 0.103 & -5.190 & 0.000 \\
\hline CAR & 0.460 & 0.202 & 2.276 & 0.028 \\
\hline Ln_TA & -0.014 & 0.011 & -1.225 & 0.228 \\
\hline
\end{tabular}

${ }^{*}$ Dependant variable: Credit Growth

* The DW - statistic is equal to 1.577 indicating that the residuals are not correlated having a value approximately

to 2 .

* The indicator of F-Statistic shows that the observed value (18.332) is greater than its critical value (4.211) so the alternative hypothesis wins and the model is globally significant.

* The VIF (variance inflation factor) indicator is used to measure if there is multicollinearity in a regression analysis. From the results is noticed that all variables have VIF values lower than 5 , showing an absence of the multicollinearity in the regression analysis.

Analyzing the results of table 3 we derive the econometric model that explains the dependent variable (credit growth) and is shown as follows:

\section{CR_GRi,t $=0.441-0.661$ UNPi,t $+0.091 \mathrm{GDP} \_G r i, t+0.592 \mathrm{INFi}, \mathrm{t}-1.197 \mathrm{INT} \_$ALLi,t +0.460 CARi,t -0.014 Ln_TAi,t}

To analyze the relation and statistical significance of Beta coefficients of the independent variables we review the values of the probability $p$. For $p$-values (observed level of significance) greater of 0.05 the influence of the independent variable on the dependent variable is unimportant when the other variables remain unchanged while for $p$-values smaller than 0.05 we refuse the hypothesis of the absence of relationship.

Hypothesis \#1. Beta coefficient of GDP growth is positive $(+0.091)$, showing a positive relationship between GDP growth and credit growth. P-value 0.046 that is lower than 0.05 showing that GDP growth has a significant impact on credit growth in the Albanian banking system. In fact this results is supported by previous studies where is noticed a positive and significant relationship between GDP growth and credit growth.

Hypothesis \#2. Beta coefficient of unemployment rate is negative $(-0.661)$, showing a negative relationship between unemployment rate and credit growth. P-value is 0.193 that is greater than 0.05 so the unemployment rate does not have any impact on credit growth in the Albanian banking system. This is contrary to previous studies where is noticed a negative relationship between unemployment rate and credit growth.

Hypothesis \#3. Beta coefficient of inflation rate is positive $(+0.592)$ showing a positive relationship between inflation rate and credit growth. P-value is 0.218 that is greater than 0.05 so the inflation rate has no impact on credit growth in the Albanian banking system. This result is contrary to previous studies where is noticed a positive relationship between inflation rate and credit growth. 
Hypothesis \#4. Beta coefficient of credit interest rate is negative (-1.197) showing a negative relationship between credit interest rates and credit growth. P-value is 0.029 that is lower than 0.05 showing that credit interest rates have a statistically significant impact on credit growth. The negative sign of beta coefficient shows that an increase in credit interest rates determines a reduction of credit growth. This result is in line with other studies in this field showing that higher credit interest rates tend to lower the credit growth.

Hypothesis \#5. Beta coefficient of nonperforming loans (NPL) is negative $(-0.533)$ showing a negative relationship between NPLs and credit growth. P-value is 0.000 and lower than 0.05 showing that NPLs have a statistically significant relationship on credit growth. The negative sign of beta coefficient shows that an increase of NPLs determines a reduction of credit growth in the Albanian banking system. This result is in line with previous studies in this field showing that banks with higher NPLs tend to reduce the credit.

Hypothesis \#6. Beta coefficient of capital adequacy ratio (CAR) is positive (0.460) showing a positive relationship between CAR and credit growth. P-value is 0.028 and lower than 0.05 showing that CAR has a statistically significant relationship on credit growth. The positive sign of beta coefficient shows that an increase of CAR determines a higher of credit growth in the Albanian banking system. This result is in line with previous studies in this field showing that banks with higher CAR tend to increase the credit level.

Hypothesis \#7. Beta coefficient of bank size measured by total assets is negative $(-0.014)$ showing a negative relationship between bank size and credit growth. P-value is 0.228 and higher than 0.05 showing that bank size has no impact on credit growth in the Albanian banking system. This result is not in line with our expectations.

\section{Conclusions}

The aim of this paper was to determine the influence of some macroeconomic and banking factors on credit growth in the Albanian banking system. We used a regression analysis to test the relationship between the dependant variable (credit growth) and GDP growth, inflation rate, unemployment rate, loan interest rate, capital adequacy ratio, bank size and NPL ratio. From the regression results we found out that unemployment rate, inflation rate and bank size do not have any significant impact on credit growth in the Albanian banking system. In this paper we derived the main following conclusions:

\# A positive and significant relationship between GDP growth and credit growth meaning that good economic conditions tend to increase the credit level in the Albanian banking system;

A negative and significant relationship between interest rates and credit growth meaning that an increase of interest rates will reduce the credit level in the Albanian banking system;

A negative and significant relationship between nonperforming loans and credit growth meaning that an increase of nonperforming loans will reduce the credit growth in the Albanian banking system;

A positive and significant relationship between capital adequacy ratio and credit growth meaning that banks with higher CAR tend to have higher credit levels.

\section{References}

[1] Analysis of Bank of Albania (2012): "Reasons why the economy is less credited" http://www.monitor.al/analiza-e-bsh-arsyet-pse-po-kreditohet-me-pak-ekonomia/

[2] Bank of Albania, 2014, "The Banking Supervision Annual Report 2013, the Bank of Albania, Tirana".

[3] Bank of Albania, "Banking statistics, Quarterly data for the period 2002-2013".

[4] Bank of Albania, "Real Sector Statistics, Quarterly data for the period 2002-2013".

[5] Constant, Fouopi Djiogap and Augustin Ngomsi (2012) "Determinants of Bank Long-term 
[6] Lending Behavior in the Central African Economic and Monetary Community (CEMAC)", Review of Economics \& Finance Submitted on 05/Jan./2012, pp 107 - 114.

[7] Francisco Rodriguez and Santiago Carbo (2000), "Microeconomic determinates of bank lending: An application to the Spanish case", pp. 1 - 24.

[8] Gerti Shijaku, Irini Kalluci (2013), "Determinants of bank credit to the private sector: the case of Albania.CIP Katalogimi ne botim BK Tirana, 36.

[9] Jonas Ladime Emmanuel Sarpong-Kumankoma Kofi A.Osei (2013), "Determinants of bank lending behavior in Ghana". Journal of Economics and Sustainable Development Vol.4, N17, 2013. pp 42-47.

[10] Kai Guo and Vahram Stepanyan (2011), "Determinants of Bank Credit in Emerging Market Economics", International Monetary Fund 2011,wp/11/51.

[11] Lucy Chernykh and K.Theodossiou (2011), "Determinants of Bank Long-term Lending Behavior: Evidence from Russia", Multinational Financial Journal, 2011, vol.15.no.3/4, pp.193-216.

[12] Ralf Ewert/Gerald Schenk/Andrea Szczesny (2000), "Determinants of Bank Lending Performance in Germany", Schmalenbach Business Review u Vol.52 u October 2000 u pp. 344-362.

[13] Ralph De Haas, Daniel Ferreira and Anita Taci (2010), "What determines the composition of banks' loan portfolios?

[14] Evidence from transition countries", Journal of Bank \& Finance 34(2010) pp. 388-398.

[15] Serpil Tomak (2013), "Determinants of commercial banks' lending behavior: Evidence from Turkey" Asian Journal of Empirical Research, 3(8)2013; pp. 933-943.

[16] Tatum Blaise and Pua Tan (2012), "Determinants of Credit Growth and Interest Margins in the Philippines and Asia". Asia and Pacific Department-International Monetary Fund WP12/123. 